| ПРОТИДІЯ ЗЛОЧИННОСТІ ТА БОРОТЬБА З КОРУПЦІЄЮ

УДК 343.98

DOI: https://doi.org/10.32631/pb.2020.3.13

\author{
СТАНІСЛАВ ІГОРОВИЧ ПЕРЛІН, \\ кандидат юридичних наук, \\ Харківський науково-дослідний \\ експертно-криміналістичний центр МВС України; \\ https://orcid.org/0000-0001-9397-2738, \\ e-mail: vladlenperlin@gmail.com;
}

\author{
СВІТЛАНА МИКОЛАЇВНА ЛОЗОВА, \\ кандидат психологічних наук, доцент, \\ Харківський науково-дослідний \\ експертно-криміналістичний центр МВС України; \\ https://orcid.org/0000-0002-3348-3331, \\ e-mail:sv.lozova@ukr.net
}

\title{
ПЕРСПЕКТИВИ ВИКОРИСТАННЯ СУЧАСНИХ ЗАСОБІВ ФОТО- ТА ВІДЕОЗЙОМКИ ПІД ЧАС РОЗСЛІДУВАННЯ ЗЛОЧИНІВ
}

\begin{abstract}
Розглянуто перспективи використання сучасних засобів фото- та відеозйомки під час розслідування злочинів. Проаналізовано технічні характеристики таких сучасних технічних засобів, як аction-камери та ендоскопи. Розглянуто action-камери як цифрові пристрої, що можуть значно розширити можливості фото- та відеофіксації перебігу і результатів слідчих (розшукових) дій. Для пошуку та фіксації доказової інформації в ускладнених умовах запропоновано використання ендоскопів. Надано пропозиції щодо упровадження зазначених засобів у криміналістичну діяльність для пошуку і фіксації доказової та орієнтуючої інформації під час проведення слідчих (розшукових) дій.
\end{abstract}

Ключові слова: засоби фото- та відеозйомки, розслідування злочинів, асtіon-камери, ендоскопи.

Оригінальна стаття

\section{Постановка проблеми}

Під час розслідування будь-яких злочинів важливими етапами роботи 3 доказами $є$ діяльність з їх пошуку та фіксації. Однак існують певні категорії злочинів, як такі, що пов'язані 3 контрабандою, використанням вибухових пристроїв, незаконним обігом наркотичних речовин тощо, в яких пошук і фіксація доказів $\epsilon$ складними процесами. Для полегшення процесу пошуку та фіксації доказів застосовується відео- і фототехніка, яка $є$ ефективним способом фіксації ходу та результатів слідчих (розшукових) дій і експертних досліджень. Докази, зібрані за допомогою такої техніки, вирізняються більшою наочністю й об'єктивністю, можливістю багаторазового відтворення.

Слід зауважити, що завдяки стрімкому технічному прогресу засоби фото- та відеозйомки швидко застарівають і втрачають свою актуальність. Тому для більш ефективної фіксації слідчих (розшукових) дій слід використовувати новітні засоби, основані на цифрових технологіях.

\section{Стан дослідження проблеми}

Дослідженнями використання судової фотографії в діяльності органів внутрішніх справ свого часу займалися С. М. Потапов [1], Н. А. Селіванов [2], М. В. Салтевський [1-3] та інші вчені-криміналісти й експерти-практики. Слід зауважити, що монографічні дослідження засобів фото- та відеофіксації у криміналістичній діяльності в Україні майже не проводяться, окремі питання фотографії розглядаються лише в навчальних посібниках із криміналістичної техніки або довідниках науково-технічних засобів, які використовуються в розслідуванні злочинів [4]. Із вітчизняних монографічних досліджень можна відзначити лише працю I. В. Постики, яка стосується теорії та практики судової (криміналістичної) фотографії (2002р.) [5]. Однак новітні засоби, основані на цифрових технологіях, що використовуються у сфері фото- та відеозйомки, залишаються майже недослідженими. 


\section{Мета і завдання дослідження}

Метою статті $\epsilon$ аналіз сучасних засобів фото- та відеозйомки, основаних на цифрових технологіях, що використовуються для фіксації інформації та її пошуку на стадії досудового розслідування. Завданнями дослідження $\epsilon$ визначення умов та особливостей використання action-камер і ендоскопів, а також надання пропозицій щодо їх упровадження в діяльність із розслідування кримінальних правопорушень.

Наукова новизна дослідження полягає в обгрунтуванні доцільності використання actionкамер та ендоскопів з метою розширення можливостей пошуку та фото- і відеофіксації перебігу та результатів слідчих (розшукових) дій у кримінальному провадженні.

\section{Виклад основного матеріалу}

У криміналістиці судова фотографія визначається як галузь криміналістичної техніки, яка розробляє фотографічні засоби, прийоми і методи виявлення, фіксації та дослідження доказів [6, с. 70]. Виходячи з наданого визначення, завданнями судової (криміналістичної) фотографії $\epsilon$ виявлення, фіксація та дослідження доказів. 3 огляду на те, що стандартно судова фотографія поділяється на судовооперативну (фіксуючу) та судово-дослідницьку (експертну), ми можемо бачити вирішення двох завдань: фіксації і дослідження. Щодо виявлення доказів за допомогою фотозйомки слід лише розглядати можливість одержання слабковидимих і невидимих деталей, слідів, ознак. Іншої інформації щодо пошуку та виявлення доказів за допомогою засобів фото- і відеозйомки в підручниках з криміналістики немає. Однак, як ми вже наголошували раніше, завдяки технічному прогресу з'являються нові засоби фото- та відеозйомки, що дозволяють розширити коло завдань, які можуть виконуватись за їх допомогою.

Яскравими прикладами сучасних технічних засобів, які доцільно впроваджувати у криміналістичну діяльність для пошуку та фіксації доказової і орієнтуючої інформації, $\epsilon$ action-камери й ендоскопи.

Action-камери - цифрові пристрої, що можуть значно розширити можливості фото- та відеофіксації як перебігу слідчих (розшукових) дій, так і деяких видів судово-експертних досліджень. Для прикладу нами було апробовано можливості action-камери «Інста 360 ONE Х» 3 можливістю зйомки 360-градусного відео і фото завдяки парі ширококутних об'єктивів по обидва боки корпусу та простому у викори- станні програмному забезпеченню. Корпус камери має подовжену закруглену форму. Максимальний розмір становить усього 115 мм, а вага - 115 г. У верхній частині виробу розташовані два модулі камери, по одному на кожному боці, а під одним з них - крихітний світлодіодний екран і дві кнопки: одна для ввімкнення і швидкого вибору режимів/параметрів зйомки, інша для активації/призупинення процесу. Нижня межа злегка сплющена, що дозволяє action-камері стояти на плоскій поверхні (рекомендується використовувати триноги або штатив). Унизу передбачено стандартне кріплення для штатива, монопода й інших допоміжних аксесуарів, а також слот для карти microSD ємністю до 128 Гб і рекомендованою швидкістю UHS-I V30. Пряма передача файлів і зарядка виконуються через роз'єм micro-USB, розташований на одному боці, а знімний акумулятор вставляється у спеціальний роз'єм на іншому. Підвищити стійкість пристрою до води можна за допомогою фірмових прозорих кейсів Venture Case (до 5 м занурення) або Dive Case (до 30 м занурення) ${ }^{1}$. Фоторежими камери: одиночне фото $360^{\circ}$, серійна зйомка, інтервальна зйомка, HDR-фото. Відеорежими: стандартне відео $360^{\circ}$, відеореєстрація $360^{\circ}$, онлайн-трансляція $360^{\circ}$, HDR-відео, Bullet Time, Timelapse.

На нашу думку, використання камер такого типу доцільно для відеофіксації ходу та результатів слідчих (розшукових) дій. Насамперед, у таких ситуаціях:

1) під час огляду місця події у випадках, коли $€$ необхідність відображення не тільки статичної обстановки події, що сталася, а й динамічної, яку складно відобразити у протоколі. Особливо це стосується місць підпалів, дорожньо-транспортних пригод, коли обстановка швидко змінюється та її потрібно зафіксувати якомога детальніше. Для проведення панорамної зйомки тепер не потрібно використовувати статичне (плавний поворот відеокамери навколо горизонтальної або вертикальної осі) або динамічне (відеокамера переміщується у просторі) панорамування. Не потрібно використовувати такий прийом, як зйомка декількома відеокамерами, який вимагає присутності ще одного спеціаліста і $€$ більш трудомістким у застосуванні;

2) під час обшуку, що дає можливість повністю фіксувати дії всіх учасників цієї слідчої (розшукової) дії у трьохмірній площині й

${ }^{1}$ Insta360 ONE X Action-камера // Insta360 : сайт. URL: https://insta360.com.ua/cameras/one-x (дата звернення: 11.09.2020). 
убезпечить від можливих зловживань або необгрунтованих підозр у підкиданні певних предметів;

3) під час пред'явлення особи для впізнання за динамічними ознаками, коли одночасно можна фіксувати всі пересування учасників: того, хто впізнає, статистів, особи, яку впізнають;

4) під час слідчого експерименту для найбільш повного, точного та виразного відображення ходу і результатів слідчої дії в динаміці.

Слід зауважити, що існує багато переваг для використання під час слідчих (розшукових) дій не звичайних фото- або відеокамер, а саме action-камер. По-перше, це можливість отримання зображення з кутом огляду $360^{\circ}$ По-друге, це можливість вже після зйомки переглядати відзнятий матеріал під будь-яким кутом, що дозволяє побачити ті об'єкти, які не привернули уваги під час первинного огляду По-третє, це можливість наближення до предметів. По-четверте, це економія ресурсів тобто використання однієї камери і технічної допомоги одного спеціаліста замість декількох. По-п'яте, це можливість підводної зйомки (максимально - 30 м) для проведення фіксації під час пошуків людини, транспортного засобу тощо у водоймах.

Зазначений тип цифрових пристроїв може бути корисним також у ході судово-експертних досліджень, які потребують аналізу певних явищ і процесів у динаміці. Наприклад, під час балістичної або вибухотехічної експертизи значно полегшується фіксація динаміки пострілу або вибуху.

Якщо йдеться про пошук і фіксацію доказової інформації в ускладнених умовах, то ефективним буде використання ендоскопів. Ендоскоп (з грец. éndon - всередині, scopéó дивлюся) - група оптичних приладів різного призначення. Розрізняють медичні і технічні ендоскопи. Технічні ендоскопи (бороскопи) використовуються для огляду важкодоступних порожнин машин і устаткування під час технічного обслуговування і оцінки працездатності $^{1}$. Слід зауважити, що ендоскопи використовуються здебільшого в медичній галузі для діагностичних досліджень (гастроскопія, бронхоскопія тощо), а також у різних галузях промисловості: автомобільній (для контролю якості виготовлення двигунів), хімічній і нафтохімічній (для проведення систематичних чи

1 Эндоскоп // Википедия : свобод. энцикл. URL: https://ru.wikipedia.org/wiki/Эндоскоп (дата звернення: 11.09.2020). аварійних оглядів трубопроводів) та інших. В Україні технічні ендоскопи (бороскопи) у криміналістичній діяльності майже не використовуються.

Поодинокими випадками $є$ використання (рекомендації щодо використання) ендоскопів під час розслідування контрабанди з метою пошуку наркотиків, зброї, вибухових речовин [7].

Для кращого розуміння можливостей використання ендоскопу у криміналістичній діяльності слід розібратися 3 його основними характеристиками та класифікаційними ознаками.

Ендоскоп - це оптичний прилад, який має освітлювальну систему і призначений для огляду внутрішніх поверхонь об'єкта контролю. За принципом роботи ендоскопи поділяються на оптико-механічні та відеоендоскопи. Приймачем інформації в оптико-механічному ендоскопі $€$ «око»- світломатеріальний носій цієї інформації. Тому ендоскоп являє собою двоканальну оптичну систему. Перший канал освітлювальний, який призначений для створення необхідного за рівнем і спектром освітлення всередині контрольованого об'єкта. Освітлювальний канал більшості сучасних ендоскопів передає світло від допоміжного приладу - освітлювального блоку - на досліджуваний об'єкт через некогерентні волоконно-оптичні джгути, що складаються з великої кількості двошарових оптичних волокон діаметром, як правило, 30-50 мкм [8].

Оптико-механічні ендоскопи поділяються на гнучкі та жорсткі. Жорсткий ендоскоп (оптична трубка) складається 3 візуальної та освітлювальної систем. Візуальна система складається з лінзової, стрижневої або градієнтної оптики, яка укладена у внутрішню металеву трубку. Освітлювальна система складається з оптичного волокна, яке розташоване між двома металевими трубками: зовнішньою та внутрішньою. Основна перевага жорстких ендоскопів - це висока роздільна здатність. Не завжди є можливість безпосередньо отримати доступ до об'єкта, або сам об'єкт має складну геометрію, наприклад котли, теплообмінники, труби водопостачання, каналізації, промислові комунікації. У цьому випадку для візуального контролю застосовують гнучкі ендоскопи. У гнучких ендоскопах візуальна система і система передачі світла складаються з волоконної оптики, змонтованої всередині гнучкої трубки 3 керованим дистальним кінцем._Канал для передачі зображення являє собою лінзовий об'єктив, який будує зображення досліджуваного об’єкта на торці кабелю для 
передачі зображення. Далі зображення передається кабелем, що складається 3 великої кількості волокон товщиною 10-12 мкм ${ }^{1}$.

На відміну від оптико-механічних (візуальних) ендоскопів, відеоендоскопи за аналогічних варіантів пристроїв освітлювального каналу містять у собі оптико-електронний перетворювач - матрицю, розташовану безпосередньо за об’єктивом на дистальній частині, і інформація передається через робочу частину електричними дротами. Такі прилади не мають окуляра, зображення можна спостерігати лише на екрані телевізійного або комп'ютерного монітора, приєднаного до відеопроцесора, як правило, поєднаного з освітлювальним блоком в одному корпусі. Мініатюризація матричних приймачів зображення дозволила створити відеоендоскопи 3 гнучкою робочою частиною діаметром 4-12 мм і довжиною до декількох десятків метрів. Роздільна здатність відеоендоскопів значно вища, ніж ендоскопів на основі волоконно-оптичних джгутів, однак здебільшого поступається роздільній здатності ендоскопів із жорсткою робочою частиною на основі лінзової оптики. Крім того, процес перетворення зображення в телевізійний сигнал і подальше його цифрування призводять до втрати інформації. Якщо кількість інформації, яка сприймається оком зображення, перевищує 2x106 біт, то у звичайній телевізійній картинці кількість інформації становить близько 0,5х106 біт [8].

Експертами Харківського НДЕКЦ МВС України було апробовано водонепроникний USB-ендоскоп-бороскоп 3 камерою. Мініатюрність камери (діаметр - 7 мм), наявність яскравого підсвічування, гнучкість і довжина кабелю дозволяють провести огляд і діагностику у важкодоступних місцях. Кут огляду становить $66^{\circ}$; регульоване підсвічування 3 6ти світлодіодів; формат зображення VGA/QVGA; роздільна здатність зображення 640x480; частота кадрів - 30 к/с; інтерфейс USB 2.0; довжина кабелю - 2 м; вага - 70 г.

За результатами апробації та аналізу основних характеристик ендоскопів пропонуємо ïх використання під час проведення таких слідчих (розшукових) дій:

1) під час огляду місця події для виявлення різних слідів і предметів. Наприклад, під

1 Визуальный контроль труднодоступных объектов с помощью технического эндоскопа // Единий центр неразрушающегося контроля : сайт. URL: http://aprioris.ru/about/blog/ tehnicheskiy-endoskop.html (дата звернення: 11.09.2020). час розслідування вбивства за допомогою ендоскопа можна побачити кров у трубі, навіть якщо злочинець намагався позбутися слідів і змити їі. Оскільки ендоскоп водонепроникний, то можна використовувати його під час огляду під водою. Наприклад, в акваріумі або у ставку на території домоволодіння;

2) під час обшуку, якщо пошук проводиться в утруднених умовах:

а) пошук у квартирі наркотичних речовин, грошей, цінностей тощо за наявності сховища в каналах вентиляції, трубах, прихованих місцях санвузлів, акваріумах, за вбудованими меблями. Наприклад, криміналіст за допомогою ендоскопа знайшов за шафою-купе мобільний телефон особи, яка підозрюється у зґвалтуванні. Під час огляду телефона було отримано інформацію щодо листування підозрюваного 3 жертвою;

б) у приватних домоволодіннях додатково 3 попередньо описаними об'єктами можуть бути досліджені криниці, ставки, водойми, що знаходяться на території домоволодіння, вигрібні ями, сміттєві баки, каналізаційні люки;

в) в автомобілях (легкових, вантажних), особливо під час розслідування контрабанди, пошуку з використанням ендоскопу можуть бути піддані спеціально переобладнані або виготовлені паливні та водяні баки, простір за передньою панеллю та декоративною обшивкою кабіни, пустоти між подвійними стінками вантажного приміщення, сховища, спеціально обладнані в балках і шасі автомашини, тощо;

г) пошук на залізничному транспорті у міжстельових просторах, ямах для постільної білизни, сховищах у службових купе, різноманітних нішах, пустотах у столиках, у поручнях, розряджених вогнегасниках тощо.

\section{Висновки}

Слід зауважити, що широкі можливості використання у слідчій практиці action-камер під час проведення слідчих (розшукових) дій дозволяють із високою точністю та повнотою відтворювати рухи, міміку, жестикуляцію осіб (під час допиту й одночасного допиту двох або більше осіб), дають більше можливостей для відображення не тільки статичної, а й динамічної обстановки (огляд місця події, обшук, пред'явлення для впізнання, слідчий експеримент) і мають багато інших переваг.

Використання у криміналістичній діяльності ендоскопів дозволить вирішити питання не тільки фіксації, а й пошуку доказової інформації в ускладнених умовах (у каналах вентиляції, трубах, прихованих місцях санвузлів, за вбудованими меблями). Водонепроникність 
ендоскопу дозволяє використовувати його для огляду під водою (у криницях, ставках, акваріумах). Крім того, ендоскоп використовується для вивчення внутрішньої будови зброї, перекриття стін і в багатьох інших випадках, коли під час експертного дослідження потрібне проникнення у важкодоступні місця. Тому перспективним напрямком слід визначити подальше дослідження action-камер та ендоскопів під час проведення судових експертиз і експертних досліджень, наприклад судово-балістичних, будівельно-технічних тощо.
Стрімкий розвиток технічного прогресу, в тому числі в галузі фото- та відеофіксації, дає можливість підвищувати ефективність проведення слідчих (розшукових) дій і експертних досліджень шляхом використання новітніх засобів, основаних на цифрових технологіях. Використання таких засобів дозволяє розширити коло завдань, які виконуються за допомогою судової (криміналістичної) фотографії, додавши, крім фіксації та дослідження, ще й пошук і виявлення доказів.

\section{Список бібліографічних посилань}

1. Потапов С. М. Судебная фотография: методы фотографирования доказательств в следственном и судебном процессе. М. ; Ленинград : Изд-во Акад. наук СССР, 1948. 204 с.

2. Селиванов Н. А., Эйсман А. А. Судебная фотография : учеб. пособие. М. : Юрид. лит., 1965. 231 с.

3. Салтевский М. В., Гапонов Ю. С. Судебная фотография и кинематография в деятельности органов внутренних дел : учеб. пособие. Киев : Изд-во КВШ МВД СССР, 1974. 159 с.

4. Науково-технічні засоби в експертній практиці: концептуальні засади : метод. посіб. / авт.упоряд.: С. І. Перлін, С. О. Шевцов. Харків : ФОП Чальцев О. В., 2009. 152 с.

5. Постика I. В. Судова (криміналістична) фотографія: теорія і практика : монографія. Одеса : Юрид. літ., 2002. 296 с.

6. Криміналістика : підручник / авт. кол.: В. М. Глібко, А. Л. Дудніков та ін. ; за ред. В. Ю. Шепітька. Київ : Ін Юре, 2001. 682 с.

7. Шевчук В. М. Основи методики розслідування контрабанди : навч. посіб. Харків : Нац. юрид. акад. України, 2001. 49 с.

8. Козачок В. С. Особливості використання ендоскопа при проведенні судово-балістичних досліджень // Теорія та практика судово-експертної діяльності : зб. наук. праць (м. Київ, 27 січ. 2019 р.) / МВС України, Нац. акад. внутр. справ. Київ, 2019. С. 209-212.

Надійшла до редколегії 14.09.2020

\section{ПЕРЛИН С. И., ЛОЗОВАЯ С. Н. ПЕРСПЕКТИВЫ ИСПОЛЬЗОВАНИЯ СОВРЕМЕННЫХ СРЕДСТВ ФОТО- И ВИДЕОСЪЕМКИ ПРИ РАССЛЕДОВАНИИ ПРЕСТУПЛЕНИЙ}

Рассмотрены перспективы использования современных средств фото-, видеосъемки при расследовании преступлений. Проанализированы технические характеристики таких современных технических средств, как action-камеры и эндоскопы. Рассмотрены action-камеры как цифровые устройства, которые могут значительно расширить возможности фото- и видеофиксации хода и результатов следственных (розыскных) действий. Для поиска и фиксации доказательственной информации в затрудненных условиях предложено использование эндоскопов. Изложены предложения по внедрению таких средств в криминалистическую деятельность для поиска и фиксации доказательственной и ориентирующей информации при проведении следственных (розыскных) действий.

Ключевые слова: средства фото- и видеосъемки, расследование преступлений, асtіonкамеры, эндоскопы.

\section{PERLIN S. I., LOZOVA S. M. PERSPECTIVES FOR THE USE OF MODERN MEANS OF PHOTOGRAPHY AND VIDEO RECORDING DURING THE INVESTIGATION OF CRIMES}

Perspectives for the use of modern means of photography and video recording within forensic activities have been studied. It has been indicated that photo and video equipment is rapidly becoming obsolete and losing its relevance, so we should use the latest tools based on digital technologies for more effective recording of investigative (search) actions.

The technical characteristics of such modern technical means as action cameras and endoscopes have been analyzed. Action cameras have been studied as digital devices that can significantly expand the possibilities of photo and video recording of the course of investigative (search) actions, as well as some types of forensic research. Extensive possibilities of using 
action cameras within investigative practice during investigative (search) actions allow to reproduce the movements, facial expressions, gestures of persons (during interrogation and simultaneous interrogation of two or more persons) with high accuracy; allow to display not only static, but also dynamic situation (crime scene search, search, presentation for identification, investigative experiment), and also provide many other advantages.

The use of endoscopes in forensic activities will solve the problem not only of fixation, but also the search for evidence in difficult conditions (in ventilation ducts, pipes, hidden places of bathrooms, built-in furniture). The waterproofness of the endoscope allows us to use it for underwater inspection (in a well, pond, aquarium). The effectiveness of the endoscope is unquestionable in studying internal structure of the weapon, the overlap of the walls and in many other cases, when penetration into hard-to-reach places is required during the expert examination.

Key words: means of photo-, video recording, crime investigation, action cameras, endoscopes. 